\title{
KUALITAS PELAYANAN PUBLIK PEMBAYARAN PAJAK KENDARAAN BERMOTOR
}

\author{
PUBLIC SERVICE QUALITY \\ OF MOTOR VEHICLE TAX PAYMENT
}

\author{
Bambang Eka Saputra ${ }^{1 *}$, Beddy Iriawan Maksudi², Euis Salbiah ${ }^{3}$ \\ 1,2,3Program Studi Administrasi Publik, Fakultas Ilmu Sosial dan Ilmu Politik, Universitas \\ Djuanda, Jl. Tol Ciawi No. 1, Kotak Pos 35, Bogor 16720 \\ *Korespondensi: Bambang Eka Saputra. Email: benk.bes@gmail.com
}

(Diterima: 12-08-2020; Ditelaah: 08-10-2020; Disetujui: 30-11-2020)

\begin{abstract}
The Program of Samsat Entering Village, known as SAMADES, is an innovation of motor vehicle tax payment service by bringing the service closer to people at villages that are far or unreachable from the Samsat Office. SAMADES is placed at locations being reachable by the community, namely village and district offices, and village meeting halls aiming to increase the public awareness and to bring the motor vehicle tax payment service closer to the community. The aim of this research is to describe the public service quality of motor vehicle tax payment in the SAMADES service of Sindang Barang, Bogor City. The measurement of service quality is based on five dimensions, namely tangibles, reliability, responsiveness, assurance and empathy. The method of this research is descriptive method combined by qualitative approach. The research samples consist of 53 people. This research uses questionnaires as main instrument of data collection. Data of this research are analyzed by counting the mean score. The results of this research indicate that the servive quality obtains mean score 3.98 perceived as good. In relation to five dimensions of service quality, dimension of assurance obtains the mean score 4.22 perceived as best, whereas dimension of tangibles obtains mean score 3.63, although including the lowest but having good evaluation of the research respondents.
\end{abstract}

Key words: Service Innovation, Public Satisfaction, Service Quality, Public Service.

\begin{abstract}
ABSTRAK
Program Samsat Masuk Desa (SAMADES) merupakan inovasi layanan pemungutan pajak kendaraan bermotor dengan cara menjemput ke desa yang selama ini jauh atau tidak terjangkau dari Kantor Samsat Induk dan Samsat Keliling. SAMADES ditempatkan di lokasi-lokasi yang mudah dijangkau oleh masyarakat, yakni kantor lurah, desa, camat dan balai pertemuan desa yang bertujuan untuk meningkatkan kesadaran masyarakat dalam membayar pajak dan mendekatkan pelayanan pembayaran pajak kendaraan bermotor kepada masyarakat. Tujuan penelitian ini adalah untuk mengetahui kualitas pelayanan publik pembayaran pajak kendaraan bermotor di pelayanan SAMADES Sindang Barang Kota Bogor. Pengukuran kualitas pelayanan didasarkan pada lima dimensi, yaitu tangibles, reliability, responsiveness, assurance, dan empathy. Metode yang digunakan dalam penelitian ini adalah metode deskriptif dengan pendekatan kualitatif. Sampel penelitian adalah sebanyak 53 orang. Penelitian ini menggunakan kuesioner/angket sebagai instrumen utama pengumpulan data. Pengolahan data dilakukan melalui penghitungan skor rerata. Hasil penelitian menunjukkan bahwa kualitas pelayanan memperoleh skor rerata sebesar 3,98 termasuk kategori baik. Dikaitkan dengan lima dimensi kualitas pelayanan, maka dimensi assurance (jaminan) memperoleh skor rerata sebesar 4,22 termasuk dalam kategori penilaian sangat baik, sedangkan dimensi tangibles (bentuk fisik) memiliki skor rerata terendah sebesar 3,63, walaupun termasuk terendah tetapi memiliki penilaian yang baik dari responden penelitian.
\end{abstract}

Kata kunci: Inovasi Layanan, Kepuasan Masyarakat, Kualitas Pelayanan, Pelayanan Publik.

Saputra, Bambang Eka; Maksudi, Beddy Iriawan \& Salbiah, Euis. (2021). Kualitas Pelayanan Publik Pembayaran Pajak Kendaraan Bermotor. Jurnal GOVERNANSI, 7(1): 29-38. 


\section{PENDAHULUAN}

Program Samsat Masuk Desa (SAMADES) merupakan inovasi layanan pemungutan pajak kendaraan bermotor dengan cara menjemput ke desa yang selama ini jauh atau tidak terjangkau dari Kantor Samsat Induk dan Samsat Keliling. Samsat Masuk Desa ditempatkan di lokasilokasi yang mudah dijangkau oleh masyarakat, yakni kantor lurah, desa, camat dan balai desa pertemuan warga yang bertujuan untuk meningkatkan kesadaran masyarakat dalam membayar pajak dan mendekatkan pelayanan pembayaran pajak kendaraan bermotor kepada masyarakat. Wajib pajak tidak harus datang ke Kantor Samsat Induk, cukup membayar pajak di Samsat Masuk Desa (SAMADES) yang buka setiap hari kecuali hari libur.

Peraturan Menteri Pendayagunaan Aparatur Negara dan Reformasi Birokrasi Nomor 17 Tahun 2017 tentang Pedoman Penilaian Kinerja Unit Penyelenggara Pelayanan Publik dan Peraturan Menteri Pendayagunaan Aparatur Negara dan Reformasi Birokrasi Nomor 30 tahun 2014 tentang Pedoman Inovasi Pelayanan Publik mengatur bahwa inovasi pelayanan publik adalah terobosan jenis pelayanan baik yang merupakan gagasan/ide kreatif orisinal dan/atau adaptasi/modifikasi yang memberikan manfaat bagi masyarakat, baik secara langsung maupun tidak langsung. Dengan pengaturan tersebut, inovasi pelayanan publik dimaksudkan dalam rangka peningkatan kualitas pelayanan publik.

Pelayanan publik yang baik dapat mencerminkan pelayanan yang berkualitas. Sebagai salah satu tempat pelayanan publik yang memberikan masukan pendapatan daerah, Kantor Bersama Samsat sudah sepantasnya berupaya untuk memberikan pelayanan terbaik atau pelayanan yang berkualitas kepada wajib pajak dalam membayar pajak kendaraan bermotor. Pelayanan pembayaran pajak kendaraan bermotor melalui Program Samsat Masuk Desa (SAMADES) Samsat dikategorikan sebagai pelayanan publik, sekaligus merupakan bentuk inovasi pelayanan publik yang dilakukan oleh Kantor Bersama Samsat dalam rangka peningkatan kualitas pelayanan publik kepada masyarakat, dalam hal ini wajib pajak kendaraan bermotor.

\section{MATERI DAN METODE}

\section{Konsep/Teori yang Relevan}

Pelayanan publik (public service) merupakan pelayanan yang diberikan oleh pemerintah kepada masyarakat sebagai salah satu tugas pokoknya. Dalam konteks ini, Savas (1982) menyamakan pelayanan publik (public service) dengan pelayanan pemerintah (government service), sehingga pelayanan pemerintah menunjuk pada penyediaan pelayanan oleh agen pemerintah yang mempergunakan pegawaipegawainya sendiri, dalam hal ini pemerintah bertindak sebagai penyedia pelayanan (service arranger) sekaligus penghasil pelayanan (service producer). Sifat publik dalam pelayanan publik tersebut menunjuk pada pelayanan yang secara eksklusif hanya disediakan oleh pemerintah sebagai sektor publik (publicly provided services) dan tidak oleh sektor swasta (private) (Budiarto, et al., 2005: 112113).

Ratminto dan Winarsih (2006: 2) mengemukakan bahwa pelayanan merupakan suatu aktivitas yang bersifat tidak kasat mata dan melibatkan pegawai atau sumber daya lain seperti sarana dan prasarana yang disediakan oleh penyelenggara pelayanan. Sinambela (2011: 5) mengatakan bahwa pelayanan publik merupakan upaya pemenuhan keinginan dan kebutuhan masyarakat oleh penyelenggara negara.

Undang-Undang Nomor 25 Tahun 2009, Pasal 1 butir (1), mengatur pelayanan publik sebagai kegiatan atau rangkaian kegiatan dalam rangka pemenuhan kebutuhan pelayanan sesuai dengan peraturan perundang-undangan bagi setiap warga negara dan penduduk atas barang, 
jasa, dan/atau pelayanan administratif yang disediakan oleh penyelenggara pelayanan publik. Pasal 1 butir (2) mengatur bahwa penyelenggara pelayanan publik adalah setiap institusi penyelenggara negara, korporasi, lembaga independen yang dibentuk berdasarkan undangundang untuk kegiatan pelayanan publik, dan badan hukum lain yang dibentuk semata-mata untuk kegiatan pelayanan publik.

Dengan demikian hakikat pelayanan yang dijalankan oleh pemerintah adalah untuk melayani masyarakat, sehingga pelayanan publik merupakan kegiatan yang dilakukan oleh aparat pemerintah dalam rangka memenuhi kebutuhan masyarakat sehingga menimbulkan kepuasan masyarakat (public satisfaction). Pelayanan yang memenuhi kebutuhan masyarakat dan menimbulkan kepuasan masyarakat dikategorikan sebagai pelayanan yang berkualitas.

Kualitas pelayanan diukur berdasarkan standar tertentu. Peraturan Menteri Pendayagunaan Aparatur Negara dan Reformasi Birokrasi Nomor 15 Tahun 2014 tentang Pedoman Standar Pelayanan mengatur tentang standar pelayanan agar pelayanan yang disediakan oleh penyelenggara pelayanan publik menjadi berkualitas. Untuk mengukur kualitas pelayanan publik, Zeithaml, Parasuraman dan Berry mengemukakan lima dimensi, yaitu tangibles, reliability, responsiveness, assurance dan empathy (Mantri, et al., 2017; Fahad, et al., 2019; Jihan, et al., 2019; Nasyita, et al., 2019; Prabowo, et al., 2018; Ridwanullah, et al., 2019; Rosadi, et al., 2020; Subarsono, 2005: 148-149).

Zeithaml, Parasuraman dan Berry menguraikan lebih lanjut dimensi-dimensi pengukuran kualitas pelayanan tersebut sebagai berikut: (1) Tangibles, yaitu fasilitas fisik, peralatan, pegawai dan fasilitasfasilitas komunikasi yang dimiliki oleh penyedia layanan. (2) Reliability, yaitu kemampuan untuk menyelenggarakan pelayanan yang dijanjikan secara akurat. (3) Responsiveness, yaitu kerelaan untuk menolong pengguna layanan dan menye- lenggarakan pelayanan secara ikhlas. (4) Assurance, yaitu pengetahuan, kesopanan, dan kemampuan para petugas penyedia layanan dalam memberikan kepercayaan kepada pengguna layanan. (5) Empathy, yaitu kemampuan memberikan perhatian kepada pengguna layanan secara individual.

\section{Metode}

Penelitian ini menggunakan metode penelitian deskriptif-kualitatif. Populasi penelitian mencakup seluruh wajib pajak di pelayanan SAMADES Sindang Barang Kota Bogor. Wajib pajak yang menggunakan pelayanan SAMADES tersebut rata-rata per pulan berjumlah 1781 orang dan per hari sekitar 60 orang. Besaran sampel (sample size) ditentukan dengan menggunakan rumus Taro Yamane sehingga diperoleh jumlah sampel sebanyak 53 wajib pajak yang dijadikan sebagai responden penelitian. Penarikan sampel responden penelitian menggunakan accidental sampling.

Data yang dibutuhkan penelitian ini mencakup data primer dan data sekunder. Penelitian ini menggunakan kuesioner/ angket sebagai instrumen utama dalam pengumpulan data primer. Di samping itu, pengumpulan data primer juga dilakukan dengan cara wawancara. Data sekunder dikumpulkan dengan cara penelitian kepustakaan dan dokumentasi.

Kuesioner/angket disusun dengan menggunakan skala Likert untuk mendapatkan data yang bersifat ordinal. Menurut Sugiono (2017), skala Likert digunakan untuk mengukur perilaku, pendapat dan persepsi seseorang atau sekelompok orang tentang fenomena tertentu, dalam penelitian ini tentang kualitas pelayanan publik pembayaran pajak kendaraan bermotor. Jawaban (pendapat dan persepsi) responden terhadap kuesioner/angket tersebut diberi skor (Tabel 1).

Tabel 1. Jawaban Responden dan Pemberian Skor

\begin{tabular}{l|c}
\hline Jawaban & Skor \\
\hline Sangat Baik & 5 \\
\hline Baik & 4 \\
\hline
\end{tabular}




\begin{tabular}{l|l}
\hline Cukup Baik & 3 \\
\hline Tidak Baik & 2 \\
\hline Sangat Tidak Baik & 1 \\
\hline
\end{tabular}

Jawaban responden penelitian terhadap kuesioner/angket dihitung skor rerata (mean score) untuk kemudian dilakukan interpretasi berdasarkan kategori penilaian (Tabel 2).

Tabel 2. Skor Rerata dan Kategori Penilaian

\begin{tabular}{l|l}
\hline Skor Rerata & Kategori Penilaian \\
\hline $4,21-5,00$ & Sangat Baik \\
\hline $3,41-4,20$ & Baik \\
\hline $3,40-2,61$ & Cukup Baik \\
\hline $1,81-2,60$ & Tidak Baik \\
\hline $1,00-1,80$ & Sangat Tidak Baik \\
\hline
\end{tabular}

\section{HASIL DAN PEMBAHASAN}

Penelitian ini mengukur kualitas pelayanan publik pembayaran pajak kendaraan bermotor di pelayanan SAMADES Sindang Barang Kota Bogor berdasarkan lima dimensi, yaitu tangibles (bentuk fisik), reliability (keandalan), responsiveness (daya tanggap), assurance (jaminan) dan empathy (empati).

\section{Dimensi Tangibles}

Tanggapan responden mengenai tempat pelayanan dalam dimensi tangibles (bentuk fisik) menunjukkan skor rerata sebesar 3,58 artinya tempat pelayanan termasuk dalam kategori baik. Hasil wawancara dengan responden menyatakan bahwa tempat dalam pelayanan SAMADES Sindang Barang Kota Bogor selalu bersih sehingga bisa membuat nyaman masyarakat/wajib pajak.

Tanggapan responden mengenai penampilan pegawai dalam dimensi tangibles (bentuk fisik) menunjukkan skor rerata sebesar 3,69 artinya penampilan pegawai termasuk dalam kategori baik. Hasil wawancara dengan responden menyatakan bahwa sudah semestinya pegawai selalu berpenampilan rapih dan sopan, dan di pelayanan SAMADES Sindang Barang Kota Bogor pegawai sudah berpenampilan sopan.
Tanggapan responden mengenai fasilitas dalam dimensi tangibles (bentuk fisik) menunjukkan skor rerata sebesar 3,83 artinya penampilan pegawai termasuk dalam kategori baik. Hasil wawancara dengan responden menyatakan bahwa fasilitas harus bisa menunjang pelayanan maka dari itu fasilitas ruang kantor, sarana komputer dan ruang tunggu harus tersedia memadai.

Tanggapan responden mengenai lokasi strategis dalam dimensi tangibles (bentuk fisik) menunjukkan skor rerata sebesar 3,43 artinya lokasi strategis termasuk dalam kategori baik. Hasil wawancara dengan beberapa responden menyatakan bahwa adanya pelayanan SAMADES di Sindang Barang Kota Bogor membantu masyarakat/wajib pajak dan bisa termasuk ke dalam kategori strategis karena selain jauh lebih dekat bisa juga mengurangi biaya perjalanan. Akan tetapi jauh dekatnya jarak berbeda-beda karena wajib pajak tersebar dimana-mana.

Tabel 3. Rekapitulasi Dimensi Tangibles

\begin{tabular}{l|lcc}
\hline No. & Item Pernyataan & Rerata & $\begin{array}{l}\text { Kategori } \\
\text { Penilaian }\end{array}$ \\
\hline 1 & $\begin{array}{l}\text { Tempat pelayanan } \\
\text { selalu terjaga } \\
\text { kebersihan dan } \\
\text { kenyamanan }\end{array}$ & 3,58 & Baik \\
\hline 2 & $\begin{array}{l}\text { Penampilan pegawai } \\
\text { selalu rapih dan } \\
\text { pantas/sopan }\end{array}$ & 3,69 & Baik \\
\hline 3 & $\begin{array}{l}\text { Fasilitas ruang } \\
\text { kantor, sarana } \\
\text { komputer dan ruang } \\
\text { tunggu tersedia } \\
\text { secara memadai dan } \\
\text { dapat berfungsi } \\
\text { dengan baik }\end{array}$ & 3,83 & Baik \\
\hline 4 & $\begin{array}{l}\text { Pelayanan memiliki } \\
\text { lokasi yang strategis } \\
\text { dan sarana parkiran } \\
\text { yang memadai }\end{array}$ & 3,43 & Baik \\
\hline Jumlah & 3,63 & Baik \\
\hline
\end{tabular}

Tabel 3 menunjukkan hasil yang baik dilihat dari rata-rata nilai dari setiap item pernyataan yang ada pada dimensi tangibles (bukti fisik) adalah 3,63 yang meliputi 
penilaian termasuk ke dalam kategori baik. Menurut Zeithaml, Parasuraman dan Berry, mengukur tangibles merupakan fasilitas fisik, peralatan, pegawai dan fasilitasfasilitas komunikasi yang dimiliki oleh penyedia layanan yang tentunya dapat menunjang pelayanan yang lebih baik.

\section{Dimensi Reliability}

Tanggapan responden mengenai sikap tanggap pegawai dalam dimensi reliability (keandalan) menunjukkan skor rerata sebesar 3,83 artinya sikap tanggap pegawai termasuk dalam kategori baik. Hasil wawancara dengan responden menyatakan bahwa pegawai tidak selalu tanggap untuk membantu wajib pajak tanpa diminta bantuan, akan tetapi jika wajib pajak menguraikan keluhannya petugas tanggap untuk membantu.

Tanggapan responden mengenai pelayanan cepat dan tepat dalam dimensi reliability (keandalan) menunjukkan skor rerata sebesar 3,81 artinya pelayanan cepat dan tepat termasuk dalam kategori baik. Hasil wawancara dengan responden menyatakan bahwa tentunya wajib pajak menginginkan pelayanan yang cepat dan pegawai yang tanggap dari segi apapun maka dari itu pegawai dituntut untuk serba bisa dan harus berempati tinggi.

Tabel 4. Rekapitulasi Dimensi Reliability

\begin{tabular}{l|lcc}
\hline No. & Item Pernyataan & Rerata & $\begin{array}{c}\text { Kategori } \\
\text { Penilaian }\end{array}$ \\
\hline 1 & $\begin{array}{l}\text { Pegawai selalu } \\
\text { tanggap membantu } \\
\text { wajib pajak yang } \\
\text { mengalami kesulitan } \\
\text { tanpa diminta } \\
\text { bantuan }\end{array}$ & 3,83 & Baik \\
\hline 2 & $\begin{array}{l}\text { Pegawai harus } \\
\text { memberikan } \\
\text { pelayanan yang } \\
\text { cepat dan tepat }\end{array}$ & 3,81 & Baik \\
\hline Jumlah & 3,82 & Baik \\
\hline
\end{tabular}

Tabel 4 menunjukkan hasil yang baik dilihat dari rata-rata nilai dari setiap item pernyataan yang ada pada dimensi reliability (keandalan) adalah 3,82 yang meliputi penilaian termasuk ke dalam kategori baik. Menurut Zeithaml, Parasuraman dan Berry, mengukur reliability merupakan kemampuan untuk menyelenggarakan pelayanan yang dijanjikan secara akurat. Indikator/ukuran pelayanan publik yang berorientasi pada proses. Dalam hal ini, reliability melihat bagaimana keakuratan pelayanan yang diberikan oleh penyelenggara pelayanan, memberikan pelayanan yang dijanjikan dengan cepat, akurat dan memuaskan tanpa membuat kesalahan apapun dan menyampaikan pelayanan sesuai dengan waktu yang disepakati.

\section{Dimensi Responsiveness}

Tanggapan responden mengenai pelayanan tepat/akurat dalam dimensi responsiveness (daya tanggap) menunjukkan skor rerata sebesar 4,15 artinya pelayanan tepat/akurat termasuk dalam kategori baik. Hasil wawancara dengan responden menyatakan bahwa pegawai harus tanggap dalam menghadapi keluhan masyarakat/wajib pajak dan memberikan solusi yang tepat/akurat.

Tanggapan responden mengenai pelayanan tanpa membedakan status atau latar belakang dalam dimensi responsiveness (daya tanggap) menunjukkan skor rerata sebesar 4,26 artinya pelayanan tanpa membedakan status atau latar belakang termasuk dalam kategori sangat baik. Hasil wawancara dengan responden menyatakan bahwa pegawai memberikan pelayanan yang sesuai dan tidak membeda-bedakan status atau latar belakang masyarakat/ wajib pajak.

Tanggapan responden mengenai pengurusan validasi pembayaran pajak selesai tepat waktu dalam dimensi responsiveness (daya tanggap) menunjukkan skor rerata sebesar 3,96 artinya pengurusan validasi pembayaran pajak selesai tepat waktu termasuk dalam kategori baik. Hasil wawancara dengan responden menyatakan bahwa dalam pengurusan pembayaran pajak termasuk kategori cepat dan tidak berbelit-belit. 
Tabel 5. Rekapitulasi Dimensi Responsiveness

\begin{tabular}{l|lcc}
\hline No. & Item Pernyataan & Rerata & $\begin{array}{c}\text { Kategori } \\
\text { Penilaian }\end{array}$ \\
\hline 1 & $\begin{array}{l}\text { Pegawai selalu } \\
\text { memberikan } \\
\text { pelayanan kepada } \\
\text { wajib pajak secara } \\
\text { akurat/tepat }\end{array}$ & 4,15 & Baik \\
\hline 2 & $\begin{array}{l}\text { Pegawai selalu } \\
\text { memberikan } \\
\text { pelayanan kepada } \\
\text { wajib pajak tanpa } \\
\text { membedakan status } \\
\text { atau latar belakang }\end{array}$ & 4,26 & $\begin{array}{c}\text { Sangat } \\
\text { Baik }\end{array}$ \\
\hline 3 & $\begin{array}{l}\text { Pengurusan validasi } \\
\text { pembayaran pajak } \\
\text { selesai tepat waktu }\end{array}$ & 3,96 & Baik \\
\hline Jumlah & 4,12 & Baik \\
\hline
\end{tabular}

Tabel 5 menunjukkan hasil yang baik dilihat dari rata-rata nilai dari setiap item pernyataan yang ada pada dimensi responsiveness (daya tanggap) adalah 4,12 yang meliputi penilaian termasuk ke dalam kategori baik. Menurut Zeithaml, Parasuraman dan Berry, mengukur responsiveness merupakan kerelaan untuk menolong masyarakat/wajib pajak dan menyelenggarakan pelayanan secara ikhlas. Responsiveness (daya tanggap) mengukur daya tanggap organisasi terhadap harapan, keinginan dan aspirasi serta tuntutan masyarakat/wajib pajak. Responsivitas atau daya tanggap merupakan kemampuan organisasi untuk mengidentifikasi kebutuhan masyarakat dan mengembangkannya dalam berbagai program pelayanan. Dalam hal ini, kemampuan pegawai untuk membantu dan merespons masyarakat/wajib pajak serta memberikan pelayanan secara cepat dan tanggap.

\section{Dimensi Assurance}

Tanggapan responden mengenai pengetahuan yang luas terhadap jenis layanan dalam dimensi assurance (jaminan) menunjukkan skor rerata sebesar 4,20 artinya pengetahuan yang luas terhadap jenis layanan termasuk dalam kategori baik. Hasil wawancara dengan responden menyatakan bahwa pentingnya pegawai memiliki pengetahuan yang luas terhadap jenis pelayanan karena sangat membantu wajib pajak.

Tanggapan responden mengenai keramahtamahan dalam dimensi assurance (jaminan) menunjukkan skor rerata sebesar 4,32 artinya keramahtamahan termasuk dalam kategori sangat baik. Hasil wawancara dengan responden menyatakan bahwa petugas mengedepankan keramahtamahan dalam pelayanan sehingga memberikan kenyamanan dan keleluasaan kepada wajib pajak dalam menyampaikan keluhannya tanpa canggung.

Tanggapan responden mengenai kesopanan dalam dimensi assurance (jaminan) menunjukkan skor rerata sebesar 4,15 artinya kesopanan termasuk dalam kategori baik. Hasil wawancara dengan responden menyatakan bahwa kesopanan dalam pelayanan merupakan poin utama karena tentunya wajib pajak ingin diperlakukan dengan sopan, sopan di sini bervariasi macamnya, maka dari itu petugas dituntut untuk mempunyai etika.

Tanggapan responden mengenai penyediaan informasi yang dapat dipercaya dalam dimensi assurance (jaminan) menunjukkan skor rerata sebesar 4,18 artinya penyediaan informasi yang dapat dipercaya termasuk dalam kategori baik. Hasil wawancara dengan responden menyatakan bahwa informasi dimaksud dalam dimensi assurance (jaminan) adalah informasi yang dapat dipercaya dari segi manapun.

Tabel 6. Rekapitulasi Dimensi Assurance

\begin{tabular}{l|lcc}
\hline No. & Item Pernyataan & Rerata & $\begin{array}{c}\text { Kategori } \\
\text { Penilaian }\end{array}$ \\
\hline 1 & $\begin{array}{l}\text { Pegawai harus } \\
\text { memiliki } \\
\text { pengetahuan yang } \\
\text { luas terhadap jenis } \\
\text { layanan }\end{array}$ & 4,20 & Baik \\
\hline 2 & $\begin{array}{l}\text { Pegawai selalu } \\
\text { mengedepankan } \\
\text { keramahtamahan } \\
\text { dalam memberikan } \\
\text { pelayanan kepada } \\
\text { wajib pajak }\end{array}$ & 4,32 & $\begin{array}{c}\text { Sangat } \\
\text { Baik }\end{array}$ \\
\hline
\end{tabular}




\begin{tabular}{l|lcc}
\hline 3 & $\begin{array}{l}\text { Pegawai selalu } \\
\text { mengedepankan } \\
\text { kesopanan dalam } \\
\text { memberikan } \\
\text { pelayanan kepada } \\
\text { wajib pajak }\end{array}$ & 4,15 & Baik \\
\hline 4 & $\begin{array}{l}\text { Pegawai selalu } \\
\text { menyediakan } \\
\text { informasi yang } \\
\text { dapat dipercaya } \\
\text { dalam memberikan } \\
\text { pelayanan kepada } \\
\text { wajib pajak }\end{array}$ & 4,18 & Baik \\
\hline
\end{tabular}

Tabel 6 menunjukkan hasil yang baik dilihat dari rata-rata nilai dari setiap item pernyataan yang ada pada dimensi assurance (jaminan) adalah 4,21 yang meliputi penilaian termasuk ke dalam kategori sangat baik. Menurut Zeithaml, Parasuraman dan Berry, mengukur assurance menggunakan kepastian adalah pengetahuan, kesopanan, dan kemampuan pegawai penyedia layanan dalam memberikan pelayanan kepada masyarakat/wajib pajak. Assurance (jaminan) mencakup perilaku pegawai yang mampu menumbuhkan kepercayaan masyarakat/wajib pajak, bersikap sopan, menguasai pengetahuan dan keterampilan untuk mengatasi masalah (komplain) masyarakat/wajib pajak, serta kemampuan untuk menciptakan rasa aman (bebas dari bahaya).

\section{Dimensi Empathy}

Tanggapan responden mengenai perhatian yang tulus dan ikhlas dalam dimensi empathy (empati) menunjukkan skor rerata sebesar 4,24 artinya perhatian yang tulus dan ikhlas termasuk dalam kategori sangat baik. Hasil wawancara dengan responden menyatakan bahwa pegawai memberikan perhatian yang tulus dan ikhlas kepada wajib pajak merupakan sikap yang elegan dalam pelayanan sehingga membuat wajib pajak merasa puas dengan pelayanan.

Tanggapan responden mengenai kemampuan memahami kebutuhan wajib pajak dalam dimensi empathy (empati) menunjukkan skor rerata sebesar 3,90 artinya kemampuan memahami kebutuhan wajib pajak termasuk dalam kategori baik. Hasil wawancara dengan responden menyatakan bahwa kemampuan memahami artinya petugas paham akan kebutuhan dan yang diinginkan wajib pajak.

Tanggapan responden mengenai pemberian informasi yang dibutuhkan oleh wajib pajak dalam dimensi empathy (empati) menunjukkan skor rerata sebesar 4,26 artinya pemberian informasi yang dibutuhkan oleh wajib pajak termasuk dalam kategori sangat baik. Hasil wawancara dengan responden menyatakan bahwa petugas memberikan informasi yang dibutuhkan tanpa kecuali.

Tabel 7. Rekapitulasi Dimensi Empathy

\begin{tabular}{l|lcc}
\hline No. & Item Pernyataan & Rerata & $\begin{array}{c}\text { Kategori } \\
\text { Penilaian }\end{array}$ \\
\hline 1 & $\begin{array}{l}\text { Pegawai } \\
\text { memberikan } \\
\text { perhatian yang tulus } \\
\text { dan ikhlas kepada } \\
\text { wajib pajak }\end{array}$ & 4,24 & $\begin{array}{c}\text { Sangat } \\
\text { Baik }\end{array}$ \\
\hline 2 & $\begin{array}{l}\text { Pegawai mampu } \\
\text { memahami } \\
\text { kebutuhan wajib } \\
\text { pajak }\end{array}$ & 3,90 & Baik \\
\hline 3 & $\begin{array}{l}\text { Pegawai selalu } \\
\text { memberikan } \\
\text { informasi yang } \\
\text { dibutuhkan oleh } \\
\text { wajib pajak }\end{array}$ & 4,26 & $\begin{array}{c}\text { Sangat } \\
\text { Baik }\end{array}$ \\
\hline \multicolumn{2}{ll}{ Jumlah } & 4,13 & Baik \\
\hline
\end{tabular}

Tabel 7 menunjukkan hasil yang baik dilihat dari rata-rata nilai dari setiap item pernyataan yang ada pada dimensi empathy (empati) adalah 4,13 yang meliputi penilaian termasuk ke dalam kategori baik. Menurut Zeithaml, Parasuraman dan Berry, mengukur empathy (empati) adalah kemampuan memberikan perhatian kepada masyarakat/wajib pajak secara individual. Empathy berarti bahwa pegawai memahami masalah masyarakat/wajib pajak, komunikasi yang baik, perhatian personal dan memahami kebutuhan masyarakat/wajib pajak, serta memiliki jam operasi yang nyaman. 
Secara keseluruhan, hasil penelitian tentang kualitas pelayanan publik pembayaran pajak kendaraan bermotor di pelayanan SAMADES Sindang Barang Kota Bogor ditunjukkan dalam rekapitulasi pada Tabel 8.

Tabel 8. Rekapitulasi Variabel Kualitas Pelayanan

\begin{tabular}{|c|c|c|}
\hline Dimensi & Rerata & $\begin{array}{c}\text { Kategori } \\
\text { Penilaian } \\
\end{array}$ \\
\hline Tangibles & 3,63 & Baik \\
\hline Reliability & 3,82 & Baik \\
\hline Responsiveness & 4,12 & Baik \\
\hline Assurance & 4,22 & Sangat Baik \\
\hline Empathy & 4,13 & Baik \\
\hline Jumlah & 3,98 & Baik \\
\hline
\end{tabular}

Pada Tabel 8, hasil penelitian tentang kualitas pelayanan publik pembayaran pajak kendaraan bermotor di pelayanan SAMADES Sindang Barang Kota Bogor menunjukkan skor rerata terhadap keseluruhan dimensi, yaitu sebesar 3,98. Hal ini menggambarkan bahwa kualitas pelayanan termasuk kategori baik sesui dengan yang diharapkan. Berdasarkan dimensi-dimensi pengukuran kualitas pelayanan yang dituangkan dalam penelitian ini, hasilnya menunjukkan kriteria baik atau sesuai dengan target yang dicapai.

Hasil penelitian tersebut yang menunjukkan kualitas pelayanan yang baik dalam pembayaran pajak kendaraan bermotor di pelayanan SAMADES Sindang Barang Kota Bogor berpengaruh terhadap kepuasan masyarakat/wajib pajak. Hal ini merupakan prasyarat dari loyalitas masyarakat/wajib pajak. Kepuasan masyarakat/wajib pajak menjadi fondasi dari loyalitas masyarakat/ wajib pajak dengan kualitas pelayanan sebagai kunci di dalamnya.

\section{KESIMPULAN DAN IMPLIKASI}

\section{Kesimpulan}

Hasil penelitian menunjukkan bahwa kualitas pelayanan publik pembayaran pajak kendaraan bermotor di pelayanan SAMADES Sindang Barang Kota Bogor memperoleh skor rerata sebesar 3,98 termasuk kategori penilaian baik. Dikaitkan dengan lima dimensi kualitas pelayanan, maka skor tertinggi pada dimensi assurance (jaminan) memperoleh skor rerata sebesar 4,22 termasuk dalam kategori penilaian sangat baik, sedangkan dimensi tangibles (bentuk fisik) memiliki skor rerata terendah sebesar 3,63, walaupun termasuk terendah tetapi memiliki penilaian yang baik dari responden penelitian.

\section{Implikasi}

Hasil penelitian tentang kualitas pelayanan publik pembayaran pajak kendaraan bermotor di pelayanan SAMADES Sindang Barang Kota Bogor dapat berimplikasi terhadap hal-hal sebagai berikut:

1. Sistem kepuasan masyarakat/wajib pajak memperhatikan aspek ketersediaan pelayanan merupakan kualitas pelayanan dan pemenuhan kebutuhan pelayanan bagi masyarakat/wajib pajak, seperti menyediakan informasi di bagian pelayanan, menugaskan pegawai untuk memberikan pelayanan sesuai dengan bidang keahlian dan pentingnya sikap ketelitian dalam proses pelayanan.

2. Sistem kepuasan masyarakat/wajib pajak memperhatikan aspek kemudahan dan kenyamanan dalam pelayanan meliputi kemudahan melakukan pembayaran, kemudahan mendaftar, adanya pelayanan yang baik ketika masyarakat/wajib pajak menyampaikan keluhan, sistem pembayaran yang mudah, kenyamanan loket atau tempat pembayaran.

3. Sistem kepuasan masyarakat/wajib pajak memperhatikan aspek ketepatan pelayanan, meliputi ketepatan waktu pelayanan, ketepatan penjelasan dari pegawai yang memberikan pelayanan.

4. Sistem kepuasan masyarakat/wajib pajak memperhatikan aspek keterbukaan informasi mencakup kemudahan memperoleh informasi yang transparan menyangkut kebutuhan pelayanan kepada masyarakat/wajib pajak. 
5. Sistem kepuasan masyarakat/wajib pajak memperhatikan aspek penilaian masyarakat/wajib pajak merupakan penilaian terhadap keseluruhan pelayanan yang telah dirasakan oleh masyarakat/wajib pajak.

6. Sistem kepuasan masyarakat/wajib pajak memperhatikan aspek kemampuan berkomunikasi menunjukkan kemampuan pegawai dalam melayani masyarakat/wajib pajak melalui komunikasi yang baik, memberikan penjelasan yang sesuai dengan kebutuhan masyarakat/wajib pajak serta melakukan umpan balik apakah yang dijelaskan sudah sesuai dengan keinginan masyarakat/wajib pajak.

\section{DAFTAR PUSTAKA}

\section{Buku}

Budiarto, Diani; Krisna, Eri \& Seran, G. Goris. (2005). Perspektif Pemerintahan Daerah: Otonomi, Birokrasi, dan Pelayanan Publik. Bogor: Penerbit FISIP Universitas Djuanda.

Ratminto dan Winarsih, Atik Septi. (2006). Manajemen Pelayanan. Yogyakarta: Pustaka Pelajar.

Sinambela, Lijan Poltak, dkk. (2011). Reformasi Pelayanan Publik. Jakarta: Bumi Aksara.

Subarsono, A. G. (2005). "Pelayanan Publik yang Efisien, Responsif, dan NonPartisan", dalam: Dwiyanto, A. (2005). Mewujudkan Good Governance Melalui Pelayanan Publik. Yogyakarta: Gadjah Mada University Press.

Sugiyono. (2017). Metode Penelitian Kuantitatif, Kualitatif, dan R\&D. Bandung: Alfabeta.

\section{Jurnal}

Fahad, Ahmad Danial; Maksudi, Beddy Iriawan \& Pratidina, Ginung. (2019). "Kualitas Pelayanan Penggantian STNK 5 Tahun di SAMSAT Cibadak Kabupaten Sukabumi". Jurnal
GOVERNANSI, 5(2): 163-169. http:// dx.doi.org/10.30997/jgs.v5i2.1780.

Jihan, Nurul Syah; Maksudi, Beddy Iriawan \& Purnamasari, Irma. (2019). "Analisis Kualitas Pelayanan Dalam Meningkatkan Kepuasan Pelanggan Kereta Api Pangrango Kelas Eksekutif Rute Bogor-Sukabumi". Jurnal GOVERNANSI, 5(1): 79-88. http://dx. doi.org/10.30997/jgs.v5i1.1708.

Mantri, Agus; Iskandar, Abu Bakar \& Purnamasari, Irma. (2017). "Pengaruh Kualitas Pelayanan terhadap Kepuasan Masyarakat pada Pembuatan Kartu Peserta Jaminan Kesehatan Nasional (JKN) di Kantor BPJS Kesehatan Kota Bogor". Jurnal GOVERNANSI, 3(2): 117-129. http://dx.doi.org/10.30997 /jgs.v3i2.937.

Nasyita, Rafa Ahdiya; Seran, G. Goris \& Salbiah, Euis. (2019). "Quality Analysis of Motor Vehicle Tax Service". Indonesian Journal of Social Research (IJSR), 1(2): 93-101. https://doi.org/ 10.30997/ijsr.v1i2.15.

Prabowo, Anugrah Dwi Cahyo; Maksudi, Beddy Iriawan \& Salbiah, Euis. (2018). "Kualitas Jasa Pelayanan Kartu Kuning (AK1) di Dinas Tenaga Kerja dan Transmigrasi Kota Bogor". Jurnal GOVERNANSI, 4(2): 66-76. http://dx. doi.org/10.30997/jgs.v4i2.1274.

Ridwanullah, Muhammad, et al. (2019). "Implementation of e-Governance to Improve the Civil Administration Service Quality in Public Sector". International Journal of Sciences: Basic and Applied Research (IJSBAR), 48(3): 168-178. https://gssrr.org/index.php /JournalOfBasicAndApplied/article/v iew/10319.

Rosadi, Rudy; Munjin, R. Akhmad \& Seran, G. Goris. (2020). "Kualitas Pelayanan Metrologi Legal Alat Timbang Pada Sektor Publik". Jurnal GOVERNANSI, 6(2): 81-92. http://dx.doi.org/10. $30997 /$ jgs.v6i2.3227. 


\section{Peraturan Perundang-undangan}

Peraturan Menteri Pendayagunaan Aparatur Negara dan Reformasi Birokrasi Nomor 15 Tahun 2014 tentang Pedoman Standar Pelayanan (Berita Negara Republik Indonesia Tahun 2014 Nomor 615).

Peraturan Menteri Pendayagunaan Aparatur Negara dan Reformasi Birokrasi Nomor 30 tahun 2014 tentang Pedoman Inovasi Pelayanan Publik (Berita Negara Republik Indonesia Tahun 2014 Nomor 1715).

Peraturan Menteri Pendayagunaan Aparatur Negara dan Reformasi Birokrasi Nomor 17 Tahun 2017 tentang Pedoman Penilaian Kinerja Unit Penyelenggara Pelayanan Publik (Berita Negara Republik Indonesia Tahun 2017 Nomor 877).

Undang-Undang Republik Indonesia Nomor 25 Tahun 2009 Tentang Pelayanan Publik (Lembaran Negara Republik Indonesia Tahun 2009 Nomor 112, Tambahan Lembaran Negara Republik Indonesia Nomor 5038). 